\title{
Torts, crimes and vindication: whose wrong is it?
}

\author{
R. A. DUFF
}

My concern in this chapter is with the implications of different conceptions of tort law for our understanding of the relationship between tort law and criminal law. I consider three conceptions of tort law (two quite briefly, a third in more detail); show how the third of them raises questions about the relationship between tort law and criminal law; discuss some ways in which we might then blur the distinction between the two kinds of law; and try to identify what must remain as the core of criminal law.

\section{Cost-allocation, civil recourse and vindication}

\section{A. Allocating the cost of harm}

If tort law was as Lord Bingham portrayed it in Watkins v. Secretary of State for the Home Department, it would be a relatively simple matter to distinguish the respective aims and proper scope of tort law and of criminal law. The 'primary role of the law of tort', he said, 'is to provide monetary compensation for those who have suffered material damage rather than to vindicate the rights of those who have not'. So a prisoner who wanted to sue the Home Office, and the prison officers who had opened his correspondence with his lawyers in breach of the Prison Rules and in bad faith, for the tort of misfeasance in public office would have to prove not merely that they had wrongfully violated his rights, but also that he had as a result suffered material, or 'special', damage; absent such damage, he would have no case under tort law. This suggests a simple, and familiar, picture of the respective operations of tort law and criminal law.

Grateful thanks for helpful comments are due to Matthew Dyson, to Nick McBride and to seminar participants at the Utrecht Centre for Accountability and Legal Liability Law.

${ }_{1}$ Watkins v. Secretary of State for the Home Department [2006] UKHL 17, [2006] 2 AC 395, [9]; quoted by J. Steele, 'Damages in tort and under the Human Rights Act: remedial or functional separation?' (2008) 67 CLJ 606, 607. 
Tort law, on this simple view, is concerned with harms and where their costs should fall. Its processes aim to allocate the costs of harm: to ensure as far as possible that they can be allocated away from those who innocently suffered them and onto those who are properly held responsible for causing them; to enable the innocent harm-sufferers to secure either a complete remedy, or at least compensation, for the harms that they suffered. This leaves open a range of questions about the principles that should determine such systematic cost-allocations - for instance, whether they should be grounded in considerations of justice, or of economic efficiency: but such questions are not our present concern. Criminal law, by contrast, on an equally simple view, is concerned not with allocating the costs of harm, but with allocating punishment for wrongs. The substantive criminal law purports, in its offence definitions, to define wrongs whose perpetrators ought to be punished (for reasons of retribution, or of prevention), and the criminal process is the procedure through which we can determine where punishments should fall, and how severe they should be.

This simple picture does seem apt for a wide range of tort cases: quite often, what a claimant properly seeks is precisely to secure the repair of, or a more or less adequate compensation for, some material damage that she has suffered, from the person or body at whose (negligent) hands she suffered it. It also neatly explains some of the salient differences between the two kinds of legal process: why a tort case is brought and controlled by the claimant, while a criminal case is brought and controlled by the polity; why tort law should involve a less demanding standard of fault, and a less demanding burden of proof, than criminal law; why pre-trial settlements without any admission of liability should be encouraged in tort cases, but not in criminal cases; and why insurance against tort awards should be allowed, or even required, whereas one cannot insure oneself against the penal burdens that flow from a criminal conviction. ${ }^{2}$

But the simple, cost-allocative, picture of tort law is, of course, far too simple: tort law is not always (even if it is sometimes) in the business of (re)allocating the costs of harm that has been caused. Tort law, many would argue, is not (just) about repairing or providing compensation for harms, but about providing suitable remedies for wrongs; and such wrong-focused accounts can make it harder to draw any clear or simple

2 See further R. A. Duff, 'Repairing harms and answering for wrongs' in J. Oberdiek (ed.), Philosophical Foundations of Tort Law (Oxford University Press, forthcoming, 2014). 
distinction between the proper aims of tort law and of criminal law especially when we address more sophisticated accounts of criminal law than the very crude account at which I gestured above. I will not attempt here to survey the entire range of competing theories of tort law; I will instead note two that do very clearly raise difficult and interesting questions about the relationship between criminal law and tort law, and discuss just one of them in more detail. My aim in discussing these accounts is not to ask whether either of them offers the best or most illuminating account of tort law - as if we should aim to explain all of tort law in terms of just one kind of aim or function - it is rather to note that they capture a kind of aim that a cost-allocative model cannot capture, but that seems to be one that the law should enable injured claimants to pursue; and to ask how that kind of aim relates to or connects with the aims that could plausibly be ascribed to the criminal law and the criminal process.

\section{B. Civil recourse as remedy for wrongs}

Consider first the 'civil recourse' model of tort law as developed by Goldberg and Zipursky. ${ }^{3}$ Civil recourse is a process through which one who has been wronged can bring a suit against the wrongdoer. The primary purpose of the suit is not, as it is on a cost-allocation model of tort law, to secure damages or compensation: it is to hold the wrongdoer to account, and to secure from the court a verdict that he is liable, for the wrong; only after such a finding of liability does the question of a remedy for that wrong arise.

The attractions of such a model should be obvious. Civil recourse offers the wronged person a process through which she can, on her own account, seek appropriate redress from the person who wronged her. That redress might ultimately involve a monetary award, since that is still, on this account, the default remedy in tort cases; that award might be calibrated to the cost of any material harm or loss that she suffered. But such an award is not the initial point of the process: the initial aim is to determine the alleged wrongdoer's liability, and to hold him accountable for the wrong if it is proved. Thus when bereaved parents sue the hospital whose negligence, they claim, caused their child's death, they will

${ }^{3}$ See especially B. C. Zipursky, 'Rights, wrongs, and recourse in the law of torts' (1998) 51 Vand LR 1; J. C. P. Goldberg and B. C. Zipursky, 'Torts as wrongs' (2010) 88 Texas LR 917 and Torts (Oxford University Press, 2010). 
if successful be awarded 'damages for bereavement' that the law sets at $£ 10,000:{ }^{4}$ But their aim in suing is not, we must hope, to secure any such sum as compensation that might even partially cover the 'costs' of the harm of their child's death: it is rather (it should be, as an aim that the law should assist) to call to account the body that wronged their child, and thus wronged them; it is to secure a formal, public verdict of liability, and thus to secure an accounting for that wrong - an accounting that will, ideally, involve a recognition of that wrong by the hospital, and an apologetic explanation of how it came to be committed.

Now it might seem that tort law as a process of civil recourse is still clearly distinguishable from the criminal law: although both deal with wrongs, civil recourse is a process through which the wronged victim can hold the wrongdoer to account, whereas criminal law is concerned with the punishments that we are collectively to impose on those who commit 'public' wrongs. That distinction begins to blur, however, once we ask more carefully what kind of 'recourse' the tort process can provide, on this view; and once we see the criminal process not simply as a process through which the allocation of penal burdens is determined, but as a communicative process of calling alleged criminal wrongdoers to account.

On this view of criminal law, the substantive criminal law's offence definitions purport to define wrongs that merit the polity's formal condemnation. In its procedural mode, the criminal law then provides for a formal response to the alleged commission of such wrongs - a response that makes their wrongfulness salient. The criminal trial calls the defendant to answer to a charge of criminal wrongdoing. If the prosecution can prove that he committed the offence charged, he must then answer for that proven criminal conduct: he must either offer an exculpatory defence, or be convicted; and a conviction condemns his conduct as criminally wrongful. That censure or condemnation is then given material force by the punishment that normally follows a conviction: for punishment can also be seen as a forceful attempt at communication, which aims to make real the offender's accountability for his crime. ${ }^{5}$ The criminal process is thus a process of calling, and holding, to account.

Something similar is also true, however, of the tort process as a mode of civil recourse. The defendant is called to answer to the claimant's claim

4 Fatal Accidents Act 1976, s. 1A(3), as amended.

5 See further R. A. Duff, Answering for Crime: Responsibility and liability in the criminal law (Oxford: Hart, 2007); and 'Towards a modest legal moralism' (2014) 8 Crim Law \& Phil 217. 
that he wronged her, and a verdict in favour of the claimant precisely holds the defendant accountable for the wrong that has been proved; as we saw, such a calling to account and such a finding of accountability are the primary aims of a civil recourse process. Furthermore, if we ask how an award of monetary damages could amount not merely to payment or compensation for such harm as the claimant suffered, but to a remedy for the wrong that was done to her, we will see that it can do so only if it is punitive: only, that is, if it is intended as a burdensome imposition on the defendant that aims to give material force to his accountability for the wrong that he committed. ${ }^{6}$

Thus it seems that both a civil recourse tort process, and the criminal process, are processes through which alleged wrongdoers are called to account; both are processes that can lead to the imposition of punitive burdens on defendants who are held liable. It will then be harder for a civil recourse theorist to explain some of the differentia between tort law and criminal law that a cost-allocative theory can quite easily explain: the kinds of defence that are available in criminal law, for instance, should surely now also be relevant in a tort case, as exculpatory ways in which a defendant can answer or account for his allegedly wrongful conduct; if the damages that a civil court awards have a punitive meaning, it is not clear that we should be able (let alone required) to insure against them. We must also now ask more carefully how tort law, understood as civil recourse, and criminal law should relate to each other. For if both aim to identify wrongs whose alleged perpetrators are to be called to public account through a judicial process, if both attach punitive burdens to findings of liability, what distinguishes their aims and functions - and how should the legal labour be divided between them? I will not pursue these questions about a civil recourse model of tort law here, since very similar questions are raised by another conception of what tort law is (sometimes) about - a conception of tort law as vindicatory.

\section{The vindication of rights}

The key issues are raised in Ashley v. Chief Constable of Sussex Police. ${ }^{7}$ The police mounted an armed raid on Mr Ashley's house at 4.20 a.m. As

\footnotetext{
6 I develop this argument in more detail in Duff, 'Repairing harms' (n. 2 above).

7 [2008] UKHL 25, [2008] 1 AC 962: see N. J. McBride, 'Trespass to the person: the effect of mistakes and alternative remedies on liability' (2008) 67 CLJ 461; P. Palmer and J. Steele,
} 
the police rushed in, Mr Ashley (having just been woken) got out of bed, naked and unarmed; he was shot and killed by a police officer. The officer was charged with murder, but was acquitted on the judge's direction, since there was no evidence to rebut his claim that he acted in selfdefence - that he believed he was being attacked, and used force that was reasonable given that belief. Members of Mr Ashley's family then sued the relevant chief constable for, inter alia, negligence and false imprisonment in relation to the planning and conduct of the raid, and assault and battery in relation to the actual shooting. The defendant admitted negligence and false imprisonment, and agreed to pay both compensatory ('basic') and aggravated damages in relation to those claims, but denied the assault and battery; he then argued that the assault and battery claim should not be allowed to proceed because, first, this would amount to a 'collateral attack' on the acquittal of the officer who shot Mr Ashley; and, second, no further damages could be awarded even if the claim succeeded. $^{8}$

The House of Lords rejected both these arguments (the second only by a 3:2 majority), for reasons that bear directly on our topic. As to self-defence, the court held that while in the criminal law an honest but mistaken belief that one was subject to lethal attack could ground a defence even if the belief was unreasonable, in tort law the defendant's mistaken belief must at least be reasonable if it is to ground a defence: the officer's acquittal on a criminal charge of murder therefore left room for a court to find for the claimant in a tort claim for assault and battery to find, for instance, that the officer acted in an honest but unreasonably mistaken belief that Mr Ashley was attacking him. Indeed, some of the law lords were tempted by the view that self-defence could provide a defence in tort law only if the belief was actually true (or at least, if mistaken, grounded in the victim's conduct in such a way that he could be said to have brought the violence on himself); but since that had not been argued by the claimants, it was not a possibility they could pursue.

'Police shootings and the role of tort' (2008) 71 MLR 801; S. Parsons and B. Andoh, 'Private defence and public defence in the criminal law and in the law of tort - a comparison' (2012) 76 J Crim L 22; more generally, K. Barker, 'Private and public: the mixed concept of vindication in torts and private law' in S. G. A. Pitel, J. W. Neyers and E. Chamberlain (eds.), Tort Law: Challenging orthodoxy (Oxford: Hart, 2013), 59; S. Smith, 'Duties, liabilities, and damages' (2012) 125 Harv LR 1727.

${ }^{8}$ It seemed clear that the defendant's admissions of liability on the other claims were intended to ward off any trial of the assault and battery claim: see Lord Scott's comments, [2008] 1 AC 962, [23]. 
As to the second issue, the court held that even if succeeding in their claim could bring the claimants no further monetary award, given what had already been conceded, the claim should be allowed to proceed: the claimants could properly seek a formal declaration by the court that Mr Ashley had been subjected to a tortious assault and battery.

Underpinning both holdings was a conception of tort law as providing for the vindication of rights: a vindication that might then be given material form in an award of vindicatory damages, but that could consist simply in an authoritative declaration by the court. ${ }^{9}$ That is why a claim can be allowed to proceed even if its success could produce no increase in the amount of damages the claimant might receive; and that is why, as we will see in more detail shortly, the criteria for the self-defence defence are quite properly different as between tort law and criminal law. By looking more closely at these two points, we can see how closely a vindicatory account of tort law is related to a civil recourse account, and how (in the law lords' eyes) tort law as thus understood is to be distinguished from criminal law.

If I complain that another person has violated my rights, and she denies it, I might then seek vindication-vindication of my claim to have been wronged, and of the rights that were, I claim, violated. Such vindication might be provided informally, by others who express their support for my claim, and condemn the violation - or even by the wrongdoer herself if she comes to accept that she wronged me; but if the right that is violated is recognised as meriting legal protection, what tort law offers me on this view is a way to secure an authoritative, formal vindication of my rights by a court's judgment. A court vindicates rights, Barker suggests, 'when it acts positively to affirm them', by 'prevent[ing] their infringement, ... declar[ing] them publicly, ... enforc[ing] them specifically ... [or] revers[ing] the effects of their infringement'. ${ }^{10}$ Our focus here must be on public declaration, in particular on declarations occurring after the right is infringed, but we should note that other modes of vindication must also be generally available. It might be true in some cases that the only mode of legal vindication available to a

9 On vindication in civil law, see generally R. Stevens, Torts and Rights (Oxford University Press, 2007), 59-91; D. Pearce and R. Halson, 'Damages for breach of contract: compensation, restitution and vindication' (2008) 28 OJLS 73; N. Witzleb and R. Carroll, 'The role of vindication in tort damages' (2009) 17 Tort LR 16; Steele, 'Damages in tort and under the Human Rights Act'(n. 1 above); Barker, 'Private and public: the mixed concept of vindication in torts and private law'(n. 7 above).

10 Barker, ibid., 68. 
wronged person is a formal, ex post declaration that her right was violated; but if such declarations are to constitute authentic vindications, they must be more than mere words: they must bring with them a commitment to take such steps as may be possible to prevent infringements, or to reverse their effects. If the law provided only for the formal declarations, but offered no substantive remedies for such wrongs, it would not vindicate the rights at issue. That is why 'vindicatory' damages may be appropriate: their award gives material force to the declaration of the right, and to this formal recognition of the wrong. Vindication and civil recourse seem to go hand in hand: one who seeks civil recourse seeks to call to public, formal account the person who wronged her; if she succeeds, the court provides a formal vindication of her claim to have been wronged, by holding the defendant liable for that wrong. It also provides, if it awards her damages that are at least in part 'vindicatory', a kind of punishment for the wrongdoer: vindicatory damages are, like those provided by civil recourse, essentially punitive, in that they can serve their expressive, symbolic purpose only if they are burdensome for the defendant.

This brings us back to a question that civil recourse raised. If the civil process is one through which an alleged wrongdoer is called to public account; if its purpose is to vindicate a right that was violated by declaring that it was violated and by imposing a punitive burden of damages on the violator: how does it differ from, or relate to, a criminal process through which an alleged wrongdoer is called to public account and, if proved guilty, is rendered liable both to a formal declaration of his guilt (a conviction), and to a burdensome punishment? Theorists of punishment sometimes suggest, explicitly or implicitly, that it serves a vindicatory purpose - even that it serves to vindicate victims' rights: ${ }^{11}$ so are we to say that the aims of tort law and of criminal law overlap in this significant way (which would raise further questions about the division of labour between them)?

Answers to this question were suggested in Ashley, and can be fleshed out by looking at the reasons why the criteria for a defence of selfdefence should differ as between criminal law and tort law. 'One of the main functions of criminal law', argued Lord Scott, 'is to identify,

11 For explicit appeals to vindication, see e.g. M. D. Dubber, Victims in the War on Crime: The use and abuse of victims' rights (New York University Press, 2002); H. A. Bedau and E. Kelly, 'Punishment' in E. Zalta (ed.), Stanford Encyclopedia of Philosophy plato. stanford.edu/archives/spr2010/entries/punishment), s. 4. 
and provide punitive sanctions for, behaviour that is categorised as criminal because it is damaging to the good order of society'; by contrast, the 'main function' of tort law 'is to identify and protect the rights that every person is entitled to assert, and require to be respected by, others', and, in cases in which rights conflict, to 'strike a balance between the conflicting rights'. He apparently took it to follow from this that in criminal law, but not in tort law, 'no one should be punished for ... the consequences of an honest mistake'. ${ }^{12}$ Lord Carswell argued that whereas ' $[\mathrm{t}]$ he criminal law has moved in recent years in the direction of emphasising individual responsibility' (so that even an unreasonably mistaken belief can ground a defence of self-defence), ' $[\mathrm{t}$ ] he function of the civil law is quite distinct. It is to provide a framework for compensation for wrongs which holds the balance fairly between the conflicting rights and interests of different people'. ${ }^{13}$ It might not be at once clear what the connection between the criterion for criminalisation identified by Lord Scott and the focus on 'individual responsibility' might be, and tort law could in any case be said to be in the business of determining 'individual responsibility'; but the thought here reflects Blackstone's classical formulation of a conception of crimes as 'public' wrongs. Whilst civil wrongs infringe 'the civil rights which belong to individuals, considered merely as individuals', crimes:

\begin{abstract}
are breach and violation of the public rights and duties, due to the whole community, considered as community, in its social aggregate capacity ... [B]esides the injury done to individuals, [crimes] strike at the very being of society, which cannot possibly subsist, where actions of [that] sort are suffered to escape with impunity. In all cases the crime includes an injury: every public offence is also a private wrong, and somewhat more; it affects the individual, and it likewise affects the community. ${ }^{14}$
\end{abstract}

Furthermore, criminal law, unlike tort law, is in the business of condemning and punishing such wrongs: but condemnation and punishment are legitimate only if they are imposed for culpable wrongdoing, which is what explains the criminal law's focus on 'individual responsibility'. We can put the matter more clearly by saying that while both criminal law and tort law are concerned with determinations

12 Ashley [2008] 1 AC 962, [17-18]. ${ }^{13}$ Ibid., [76].

14 Sir William Blackstone, Commentaries on the Laws of England (Oxford: Clarendon Press, 1765-9; available at avalon.law.yale.edu/subject_menus/blackstone.asp), Bk IV, ch. 1, p. 5. 
of individual responsibility, the different functions of the two types of law require different criteria of responsibility, or of liability. ${ }^{15}$ Criminal liability is liability for the culpable commission of a wrong, which merits condemnation and punishment; the focus of the criminal trial is on whether the defendant committed such a wrong. Tort liability, by contrast, is liability for the infringement of the claimant's legally protected rights, which requires a formal acknowledgement and (if possible) remedy: the focus of the tort case is thus on whether the claimant suffered such an infringement at the defendant's hands. The conditions of liability may therefore differ between the two contexts. We cannot explore the full range of such differences here, but can illustrate the point by returning to the example of self-defence.

In two kinds of case, the basic question that is asked in each kind of case receives the same answer. If $\mathrm{D}$ mounted an unprovoked attack on $\mathrm{P}$ without justification or excuse, he is criminally liable as having culpably committed the wrong of battery, wounding or homicide; and he is civilly liable as having violated P's right not to have such violence used against her. On the other hand, if $\mathrm{P}$ had mounted a potentially lethal attack on D, and D had used reasonable force to repel it, D is neither criminally nor civilly liable: he did not culpably commit a criminal wrong; P cannot complain that her rights were violated or even infringed, since the right that others not subject me to violence is not a right that they not subject me to violence even if I attack them. ${ }^{16}$ Matters become trickier, however, if $\mathrm{D}$ acted on the basis of a mistaken belief that $\mathrm{P}$ was attacking him - a belief such that, had it been true, the violence he used would have been reasonable. ${ }^{17}$

Suppose first that his belief, although he did hold and act on it, was quite unreasonable: that is, he had no good reason to believe that $\mathrm{P}$ was attacking him. English criminal law still allows him a defence

15 I think it is clearer to talk in this context of liability than of responsibility: see Duff, Answering for Crime (n. 5 above), ch. 1. See also the discussion by Sullivan in Chapter 4 of this volume; as well as Goudkamp's comments on the 'defendant-oriented agenda' of the criminal law as contrasted with the 'bilateral structure' of tort law in Chapter 8 (text following n. 33).

16 There is much more to be said about how we should understand the right of self-defence and its relationship to the rights of the attacker, and matters become more complicated when we consider cases of 'innocent attackers' or 'innocent threats' who threaten (perhaps intentionally) another's life, but cannot be held culpable for doing so. Fortunately, we need not consider these issues here; we need only say that if I intentionally use injurious force against a culpable attacker, I do not infringe her rights.

17 On the wider issues here, see Goudkamp's Chapter 8 in this volume. 
of self-defence, ${ }^{18}$ but the court in Ashley made clear that he could not claim a tort defence. Lord Scott's explanation of this difference was not helped by his apparent sliding back and forth between issues of justification and of excuse, ${ }^{19}$ but it is easy enough to reconstruct the relevant argument. One who acts on the basis of such an unreasonable belief cannot claim that he was justified in acting thus: the most he can claim is an excuse. But an excuse leaves intact the claim made by $\mathrm{P}$ that he violated her rights: as is often said, while justifications might negate the wrongfulness of the action justified (on which I will comment below), an excuse admits that my action was wrongful, but denies that I should be blamed for it; ${ }^{20}$ the fact that $\mathrm{D}$ had an excuse for what he did cannot negate the wrong that he did to $\mathrm{P}$. Thus $\mathrm{D}$ might hope to avoid being condemned as a culpable wrongdoer; but he must still recognise that he has wronged $\mathrm{P}$, and that he owes her something to mark his regretful recognition of that wrong.

It might be said that this difference between the criminal and the civil law simply reflects the way in which the criminal law is still unduly in thrall to legal subjectivism: that we should treat a mistaken belief in the context of self-defence as we now treat it in the context of rape, and allow it to exculpate only if it is reasonable. ${ }^{21}$ There is certainly merit in this argument, but it does not affect the point at issue here, since the reasons for not allowing unreasonable mistakes to ground a defence differ between criminal law and tort law. In tort law, what matters is whether the fact that $\mathrm{D}$ acted in the belief that $\mathrm{P}$ was attacking him negates the violation of $\mathrm{P}$ 's rights that his use of violence prima facie involved; the answer must be that it cannot. By contrast, in criminal law the question is whether that fact negates D's culpability: this question embroils us in the debates between 'subjectivist' and 'objectivist' conceptions of criminal liability, which (at least as far as defences are concerned) do not bear on the tort law question, since they do not bear on whether the claimant's rights were violated.

Suppose now, however, that D's belief that $\mathrm{P}$ was attacking him was reasonable? This must, even in the eyes of those who would not allow

18 R v. Williams (Gladstone) [1987] 3 All ER 411; see Ashley [2008] 1 AC 962, [17] (Lord Scott).

19 [2008] 1 AC 962, [18].

20 See classically J. L. Austin, 'A plea for excuses' in his Philosophical Papers (Oxford: Clarendon Press, 1961), 123, 125.

${ }^{21}$ See Sexual Offences Act 2003, s. 1; it is curious that in Ashley Lord Scott seemed to have forgotten this change in the law of rape: [2008] 1 AC 962, [18]. 
unreasonable beliefs to exculpate, save him from a criminal conviction; but should it bar civil liability? Some of the law lords in Ashley saw force in the argument that it should not, ${ }^{22}$ and we can see now why they were right. We need first to distinguish two kinds of case: in one, what gives $\mathrm{D}$ good reason to believe that $\mathrm{P}$ is attacking him is precisely P's own conduct - more precisely, $\mathrm{P}$ acts in a way that she knows will give $\mathrm{D}$ good reason to believe that she is attacking him; in the other, D's reasons for that belief are grounded in something other than P's own conduct - for instance, in what others told him about $\mathrm{P}^{23}$

If $\mathrm{P}$ gave $\mathrm{D}$ good reason to believe that she was attacking him, Lord Scott thought that 'the rules relating to contributory fault can come into play. ${ }^{24}$ It matters, of course, how P's conduct gave D reason for this belief: did she intend to induce it; or realise that he would or might form it; or fail to attend sufficiently to the risk that he would do so; or act in a way that she could not have been expected to know would give D any reason for such a belief? In the extreme case in which $\mathrm{P}$ deliberately induces the belief, we might not talk of 'contributory fault', as if there was a violation of P's rights for which $\mathrm{P}$ herself was at least partly to blame, but class it with cases in which $\mathrm{P}$ is indeed attacking $\mathrm{D} ;{ }^{25}$ in other cases we might talk of contributory fault. The crucial point, however, is that insofar as we can say that $\mathrm{P}$ wilfully gave $\mathrm{D}$ good reason to believe that she was attacking him, she is ill placed to complain if he then uses force to ward off the supposed attack: whether we say that her rights were not then infringed (as in cases of real self-defence), or that their infringement was justified by her conduct, or that she was to blame for their violation, or that she is estopped from demanding a remedy from $\mathrm{D},{ }^{26}$ her conduct gives $\mathrm{D}$ a defence. He also has a criminal defence: if he acted on a reasonable belief, based on such grounds, his use of violence against $\mathrm{P}$ did not display the disregard for her rights that could warrant conviction.

What of the case in which D's belief was based on something other than P's wilful conduct: for instance, on the briefing he was given before a police raid in the course of which he shot $\mathrm{P}$, or on information that $\mathrm{P}$ was

22 See [2008] 1 AC 962, [20] (Lord Scott), [55] (Lord Rodger reserving his opinion), [89-90] (Lord Neuberger, noting the question open but leaving it open); contrast [76] (Lord Carswell, rejecting the argument).

23 Ibid., [20] (Lord Scott), [54] (Lord Rodger), [91] (Lord Neuberger). ${ }^{24}$ Ibid., [20].

25 Cf. the discussion of self-defence and reasonable belief in A. Ripstein, Equality, Responsibility, and the Law (Cambridge University Press, 1999), 191-201.

26 Cf. McBride, 'Trespass to the person'(n. 7 above), 463. 
an armed and dangerous escaped criminal who had already tried to kill other police officers? ${ }^{27}$ Even here, the belief's grounds would surely need to include something done by $\mathrm{P}$-getting out of bed and moving towards $\mathrm{D}$, reaching for the glove compartment in the car: but P's conduct is entirely innocent in both fact and P's conception of it, and interpreted as threatening only in the light of such other factors as what D was told by others. Some might deny that a belief (one on which D is to act) that is not warranted by P's own wilful conduct should count as 'reasonable', but that seems too strict: it could surely sometimes be reasonable for $\mathrm{D}$ to misinterpret P's conduct in the light of what he was told by sources whom he had no reason to mistrust, especially if $\mathrm{D}$ had also taken whatever steps he could reasonably take to verify that information. We might hold that in the case of consent to sexual penetration, a mistaken belief should count as reasonable only if it is grounded in the conduct of the person whose consent is needed - that a $\mathrm{D}$ who believes that $\mathrm{P}$ consents only because her husband told him that she did or would consent is not acting in a reasonable belief in her consent: ${ }^{28}$ but in the context of self-defence, when waiting to make further checks might be fatal, that requirement seems too harsh; there may be cases in which $\mathrm{D}$ uses violence against $\mathrm{P}$ on the basis of a mistaken belief that $\mathrm{P}$ is attacking him, and in which that belief is both reasonable and not something for which $\mathrm{P}$ could be plausibly said to share responsibility. $\mathrm{D}$ certainly then has a defence to a criminal charge; but should he have a defence if $\mathrm{P}$ sues him for assault and battery?

It might be argued that, since D's conduct is in that case justified, he should have a defence against both the criminal charge and the civil suit. But that would be too quick, for two reasons. First, there is room for familiar dispute about whether in such cases of 'putative justification' we should say that D's conduct is justified (because he acted reasonably on the basis of a reasonable belief); or that it was excusable (because the force he used was not actually necessary to protect himself, but he was not culpable for using it given his reasonable belief); or, perhaps, that it was neither justified nor excused, but 'warranted' (because he acted

27 We could imagine a suitable version of Stephen Waldorfs story here: he was an innocent person who had the misfortune to be sitting in the car of the supposed girlfriend of an escaped prisoner who had previously shot at police officers; the police officers who shot him, in an attempt to capture him, claimed that he reached for the glove compartment and that they believed he was reaching for a gun.

${ }^{28}$ Cf. the facts of DPP v. Morgan [1976] AC 182: even had the defendants' story been true, they would have been (properly) convicted under s. 1 of the Sexual Offences Act 2003. 
reasonably but wrongly on the basis of a reasonable but mistaken belief). ${ }^{29}$ If we should describe D's conduct as excused, or as warranted, rather than as justified, we should also accept that $\mathrm{P}$ has been wronged, although $\mathrm{D}$ is not to be blamed for that wrong; and what $\mathrm{P}$ is claiming, in a vindicative tort suit, is recognition of that wrong. Second, even if we should count D's conduct as justified, that does not settle the question of whether P's claim should succeed. If $\mathrm{P}$ was actually attacking $\mathrm{D}$, or wilfully gave D good reason to believe that she was attacking him, D's use of force is justified as consistent with $\mathrm{P}$ 's rights $-\mathrm{P}$ is not wronged. But if what justifies D's action is something other than P's wilful conduct, we should rather say that $\mathrm{P}$ is justifiably wronged; her rights are justifiably infringed. Putting the matter in this way captures the crucial point that $\mathrm{P}$ was an innocent victim who was deliberately harmed even though she had done nothing to warrant or invite such violence.

We cannot embark here on a full discussion of the question of whether justifications should always be taken to negate wrongfulness, so that if D's action is justified it is consistent with P's rights; or should sometimes be taken to justify the commission of a wrong, or the infringement of P's rights. ${ }^{30}$ My own sympathies lie with the view that we should at least sometimes talk of the justified infringement of rights, which is also a way of talking about the justified commission of wrongs; but even those who reject such a view should accept that in a case in which D's action is not justified by P's own wilful conduct, $\mathrm{P}$ had a claim - the claim not to be subject to deliberate violence at D's hands - that has not been met, through no fault of P's; and that even if D's action is justified, $P$ therefore now has a legitimate claim to vindication - to some formal recognition of and response to the frustration of his claim not to be subjected to such violence. It is true that the character of that recognition and response might be conditioned by a recognition that D's action was justified, as it might be conditioned if $\mathrm{D}$ had an excuse for his conduct; but if we are to take P's right-related claims seriously, if we are to give them (and P) the respect that is required, we must take notice of their frustration. That taking notice need not always involve a formal legal

${ }^{29}$ For an argument for this suggestion, see Duff, Answering for Crime (n. 5 above), 271-7.

30 On the latter view we would distinguish 'infringements' from 'violations' of rights: to say that P's rights were infringed leaves open the possibility that that infringement was justified; to say that they were violated is to say that the infringement was not justified. But see J. Oberdiek, 'Lost in moral space: on the infringing/violating distinction and its place in the theory of rights' (2004) 23 Law \& Phil 325. 
process: it might be enough that $\mathrm{D}$ offers $\mathrm{P}$ an apologetic recognition of, and perhaps material reparation for, what he did to her. However, if the right upon which D's conduct impinged is one that merits legal recognition, $\mathrm{P}$ should be able to seek formal, public vindication through a legal process - which is what makes a vindicatory tort law appropriate.

Here is the position we have reached. When a legally recognised and protected right of P's is, through no fault of P's, infringed by $\mathrm{D}, \mathrm{P}$ can legitimately seek vindication: that vindication might be provided voluntarily by $\mathrm{D}$, without a formal legal process; but if $\mathrm{D}$ is not willing to do this, $\mathrm{P}$ should be able to seek legal recourse - a formal vindication of her right in a court of law. Sometimes, it might be said, such vindication can be provided by the criminal court, which, in convicting $\mathrm{D}$ of a criminal attack on P, thereby vindicates P's rights: but, especially if the focus of the criminal law is as Lord Scott described it in Ashley, this does not seem adequate. Even if $\mathrm{D}$ is convicted, $\mathrm{P}$ might feel left out of the process: for she did not initiate or control it ( $\mathrm{D}$ is called to account by Regina, not by $\mathrm{P}$ ); in addition, if Lord Scott is right, what $\mathrm{D}$ is called to account for is not the wrong that he did to $\mathrm{P}$ so much as the damage he did 'to the good order of society'. ${ }^{31}$ There are also, as we have seen, cases in which $\mathrm{D}$ is entitled to a criminal acquittal, because his action was excused, or justified on grounds other than P's own wilful conduct, but in which $\mathrm{P}$ is still entitled to some vindication, which is clearly not provided by D's acquittal. It might emerge during the trial that P's rights were (justifiably or excusably) infringed; but given the focus of the criminal trial, that might not emerge clearly, and is not given formal force in the acquittal. What tort law, understood in vindicatory terms, then offers $\mathrm{P}$ is precisely a process through which she can seek and obtain the vindication that she is entitled to expect, but that the criminal process does not offer her.

Might this then offer us a neat (at least in principle) distinction between criminal law and tort law - at least the elements of tort law that are concerned with the vindication of rights? Criminal law is concerned with conduct that threatens 'the good order of society'. We will therefore have reason to criminalise D's infringement of P's rights if and because it has such implications for or effects on that good order; and we must so define criminal offences and defences that $\mathrm{D}$ will be liable to conviction only if his conduct threatens that good order unjustifiably and

31 Ashley [2008] 1 AC 962, [17]. 
inexcusably. The vindicatory aspect of tort law, by contrast, is concerned with the vindication of rights when they have been infringed or violated with providing a formal recognition of and remedies for such infringements and violations; the kinds of excuse or justification that might save D from criminal liability might therefore not save him from tort liability.

This distinction, however, seems too neat-as well as leaving underexplained the idea of the 'good order of society' as the primary focus of the criminal law; in particular, it seems to remove the wrong that $\mathrm{P}$ has suffered from the focus of the criminal law in a way that should worry us. I will explain this problem, and explore some ways of dealing with it, in the following section.

\section{Civil and criminal wrongs \\ A. 'Public' and 'private' wrongs}

Lord Scott's comment that 'behaviour ... is categorised as criminal because it is damaging to the good order of society' locates him firmly, as we saw, in a familiar tradition of attempts to explain the distinctive realm of criminal law: crimes are 'public' wrongs, and what constitutes a wrong as 'public' is that it has some adverse wrongful impact on or implications for 'the public', i.e. the polity as a whole. ${ }^{32}$ We might talk of 'the good order of society' that the wrong threatens, or that would be threatened if such wrongs could be committed with impunity; of the 'social volatility' that such wrongs produce; ${ }^{33}$ of the ways in which they undermine the trust on which social life depends; ${ }^{34}$ or, more abstractly, of the unfair advantage that those who commit such wrongs take over all those who refrain from them. ${ }^{35}$ The effect of such accounts is to separate the particular, substantive wrong done to the victim of a crime (when there is a victim) from the wrong done to 'the public'; this might naturally lead us to suppose that the wrong done to the victim should fall within the realm of tort law, as a matter for him to pursue by a civil suit if

2 See Ashley [2008] 1 AC 962, [17], and text at nn. 12-14 above, in particular Blackstone's account of crimes as public wrongs.

33 L. C. Becker, 'Criminal attempts and the theory of the law of crimes' (1974) 3 Philosophy \& Public Affairs 262.

34 S. Dimock, 'Retributivism and trust' (1997) 16 Law \& Phil 37.

35 E.g. R. Dagger, 'Punishment as fair play' (2008) 14 Res Publica 259. 
he wants vindication or a remedy, while the wrong done to the public is the proper concern of the criminal law.

This kind of separation fits the two salient differentia between a tort process and a criminal process. First, the tort process is controlled by the claimant, since its focus is on her wrong - the wrong done to her: if the wrong is hers, it should be for her to decide whether, and how far, to pursue it. The criminal process, by contrast, is controlled by the polity, since the criminal wrong is theirs: it is for them collectively, through the delegated authority of their officials, to decide whether and how to pursue it. Second, a successful tort suit leads to an award that aims to benefit the claimant: she receives the damages, apology, or whatever other remedy the court orders, since it is she who seeks vindication or remedy for her wrong. A successful prosecution, by contrast, leads to a punishment that is not intended to benefit the individual victim: it is a collective matter for the polity, not something that should be left to the discretion of the individual victim - which is why it is so natural to talk of offenders as paying their 'debt to society' through punishment. ${ }^{36}$ Insofar as criminal punishment should be understood in retributive terms, it should be a matter for the polity, not for the individual victim, to determine whether justice demands the imposition of a penal burden on the offender. Insofar as its aims are preventive, that is also a matter for the polity rather than for the individual victim. Tort law serves the interests of individual victims of wrongs, and provides for the recognition and enforcement of their rights. It deals with wrongs that are 'public' in the sense that they are recognised as wrongs by the law, which provides a process through which those who suffer them can call those who commit them to public account; they do not belong only in the 'private' spheres of our extra-legal lives. ${ }^{37}$ But they are 'private' in the sense that they are seen as properly belonging to the particular claimant (and defendant) whose interests are at stake. ${ }^{38}$ Criminal law, by contrast, serves the public interest - the collective interest of members of the polity in the

36 Or indeed, in the eyes of contemporary penal policy makers, of 'community payback' rather than 'community service'. I leave aside here the complicating possibility of compensation orders: see text at n. 51 below.

37 See A. Y. Lee, 'Public wrongs and the criminal law' (2014) 8 Crim Law \& Phil (forthcoming).

38 Notions of 'the public interest' might figure, as they did in Ashley, as potential reasons for not allowing a tort suit to proceed; but that is to say only that the law here as elsewhere might bar the pursuit of private interests if it would impinge adversely on the public interest. 
preservation of good order and of the other requisites for social life, and in the demands of justice. Or we might talk, in more abstract terms, of the public interest in the preservation and vindication of the values by which the polity defines itself as a political community: we could say that whilst tort law vindicates the rights of individuals who have been wronged, criminal law vindicates the Right - the values that crimes violate. Tort law thus overlaps with criminal law in that the same conduct might constitute both a tort and a crime (although we should not forget that many criminal offences are not also torts, since they lack any identifiable victim who could be a claimant); but they do not deal with the same wrongs.

However, this kind of separation between the private wrongs that properly concern tort law, and the public wrongs that properly concern criminal law, is problematic, for several reasons. It does not sit well with the way in which prosecutors describe the crimes with which defendants stand charged, or judges describe those crimes when sentencing convicted offenders: for in the case of victimising crimes, the focus is on the substantive wrong that the defendant (allegedly) did to the particular victim. Prosecutors and judges do not usually describe the crime of the murderer, the mugger, the rapist, the burglar, in terms of the damage it did to good order; they focus on what was done to the individual victim. Furthermore, this seems right: if the criminal case was focused instead on the kinds of public interest sketched above, this would add further force to the familiar complaint that it does not do justice to victims. The charge might not now be that the criminal law 'steals' their 'conflicts', ${ }^{39}$ since on this view the victim's 'conflict' is left to be pursued through the civil law; the charge is rather that it fails to give victims the recognition and support to which they are entitled. It is as if we collectively say to them, 'Our concern is with the public interest, and the wrong done to us collectively; if you want to pursue your wrong, that is up to you'. That way of putting it is admittedly distorted, since we provide the civil process through which the victim can pursue 'her' wrongdoer - a process that can lead to an authoritative verdict in her favour and an enforceable remedy. It is still true, however, that on this view the polity leaves the victim with the burden of pursuing her own grievance - a burden that is not just material (though legal aid could be made available) and psychological, but moral: it is left to her to take up the task of calling the person who wronged her to account.

39 See, famously, N. Christie, 'Conflicts as property' (1977) 17 British Journal of Criminology 1. 
It might be said that I have misrepresented the relationship between the victim's wrong and the public interest considerations that warrant criminalising the wrongful conduct: that the wrong done to the public interest is not the focus of the criminal process, as I portrayed it above, but a condition that must be met if we are to treat the wrong done to the individual victim as a public, criminal wrong. A criminal trial is still focused on the substantive wrong done to the individual victim; but that kind of wrong can become the business of the criminal law only because it has further implications for the public interest. Even this seems inadequate, however, since it implies that we take a collective interest in the victim's wrong only because that will protect or benefit our collective, public interests. ${ }^{40}$ If we are to accord each other the 'equal concern and respect' that citizens of a liberal polity should be able to expect, ${ }^{41}$ we surely owe the victims of serious wrongs something more than this. What more we owe them, in this context, could be described as solidarity: ${ }^{42}$ if we are to treat them as fellow members of the political community, we must not just recognise (as if from a detached perspective) that they have been wronged, but must share in that wrong with them - we must make the wrong not just his or her wrong, but our wrong. ${ }^{43}$ To make it our wrong is not to make it our wrong rather than the victim's, or to 'steal' it from her: rather, it is to make it clear (and true) that we stand with the victim, as a 'we' that includes the victim, against the wrongdoer. He is still called to answer for the wrong that he did to the victim, not for some distinct wrong that he did to us; but in virtue of our community with the victim, we treat the wrong as one done not (just) to the victim, but to us collectively. Rather than leaving the victim with the burden of calling the wrongdoer to account, we join with the victim, and call him to account to us. (We also owe solidarity to the alleged wrongdoer. This is partly because what we begin with is often not an undeniable wrong done to an

40 We might even be accused of using the victim and her wrong as a means to our collective good, in a variation on the familiar objection that preventive penal practices use those punished as means to some social good.

41 See R. M. Dworkin, 'Liberal community' (1989) 77 California LR 479.

42 Cf. R. Rorty, Contingency, Irony, and Solidarity (Cambridge University Press, 1989): one need not share Rorty's particular brand of anti-foundationalism (or 'postmodernism' in one of the many senses of that term) to recognise the importance of his emphasis on solidarity as the cement of a liberal society.

43 See further S. E. Marshall and R. A. Duff, 'Criminalization and sharing wrongs' (1998) 11 Canadian Journal of Law and Jurisprudence, 7-22; 'Public and private wrongs' in J. Chalmers et al. (eds.), Essays in Criminal Law in Honour of Sir Gerald Gordon (Edinburgh University Press, 2010), 70. 
undeniable victim, but an alleged wrong done to a complainant; not an undeniable wrongdoer who is to be held to account, but an alleged wrongdoer who should be protected against over-hasty condemnation. It is also because we owe solidarity even to undoubted and proven wrongdoers, as well as with their victims: they too are, and must be recognised and treated as, fellow members of the polity. ${ }^{44}$ )

On this view, criminal law (or at least the criminal process) is quite closely related to tort law understood as offering vindication: in both the criminal and the civil context, the process is one through which an alleged wrongdoer is called to account by, and to, those whom he wronged - the individual victim, or the whole polity standing with the victim. ${ }^{45}$ We might say something similar about criminal offences that lack any identifiable, direct victim whose wrong we could collectively share. There are many such offences, including most obviously many so-called mala prohibita, consisting in the breach of regulations that serve some aspect of the public good, or to protect us collectively against certain kinds of harm; offences of endangerment that might expose no identifiable individuals to direct risk; offences of defrauding the public purse; and offences that threaten the effective operations of our essential institutions and services. In these cases, we may say, the polity as a whole is the only victim, and it must therefore be the polity that calls the wrongdoer to account.

This might suggest that every legally cognisable wrong should be defined either as civil or as criminal, but not both: it should be pursuable either as a tort through the civil courts or as a crime through the criminal courts, but that no wrong should be both a tort and a crime, since if a wrong is pursued as a crime that provides its victim with such vindication as the law should offer. This would leave us with an in principle neat process of deciding the proper scope of both tort law and criminal law. We begin with an account of the realm of public wrongs, wrongs of which the law should take cognisance; ${ }^{46}$ we then decide which of those wrongs should be torts, to be pursued by their victims if they so wish, in order to obtain vindication for themselves; and which should be criminal, to be pursued collectively as wrongs that we share with the victim.

44 See further R. A. Duff, 'A criminal law for citizens' (2010) 14 Theoretical Criminology 293.

45 For this view of the criminal trial, see R. A. Duff, L. Farmer, S. E. Marshall, V. Tadros, The Trial on Trial (3): Towards a normative theory of the criminal trial (Oxford: Hart, 2007).

46 On this process, and how it must be grounded in a political theory of the res publica or public realm, see further Duff, 'Towards a modest legal moralism' (n. 5 above). 
But, apart from the question of how we are to go about making such decisions, matters are not that simple, even in principle.

\section{B. Tort processes and criminal processes: blurring the boundaries?}

There remain three important differences between the tort process and the criminal process - differences to do with ways in which the criminal process focuses on the defendant, and the tort process on the claimant/ victim.

First, a criminal process results, if the prosecution proves its case, in a verdict that constitutes an unequivocal censure of the defendant as a wrongdoer, which is not true of a tort process. The point is not just that a tort verdict for the claimant does not carry a formally or explicitly censorial meaning in the way that a criminal verdict of 'Guilty' does although that is certainly important. More than that, as we saw in the previous section, while a tort verdict for the claimant declares that the defendant wronged her, it might not declare that he did so culpably; he might have had a justification or an excuse that should save him from censure without negating the claim that he wronged the claimant. At the same time, a criminal process that leads to an acquittal can, as we have seen, leave the wronged victim without the vindication that she might reasonably seek: it leaves undefeated the presumption of innocence - that the defendant did not culpably wrong the complainant; but it may be silent on whether the complainant was wronged by the defendant.

Second, though the damages awarded to a successful claimant who seeks vindication must, as I suggested, have a punitive meaning, they are still crucially different from criminal punishment. ${ }^{47}$ Their focus is on what is owed to the claimant, if not as compensation then by way of apologetic, symbolic reparation; but although it is common to talk of the debt that offenders owe to 'society' and pay through punishment, traditional justifications of criminal punishment do not portray it in such compensatory or reparative terms. Some portray it as a matter of retribution, which seems to focus on what is owed to the offender by way of punitive suffering rather than on what he owes to others. Others portray it in preventive terms, as aiming to deter, to incapacitate, or to reform

47 And damages awarded to a claimant who was wronged by a non-culpable defendant are not straightforwardly punitive. They are apologetic, expressing a recognition of the wrong that the defendant owes to the victim; but they do not mark the defendant's culpable guilt. 
potential offenders; but whilst tort damages might play a deterrent role, that does not seem to be their primary function.

Third, the criminal process is still controlled not by the claimant/ victim, but by the polity: we do not just offer the victim our solidarity and support, but insist on providing it - on making the victim's wrong our own, whether she likes it or not. In fact, of course, victims can often stop the prosecution of the person who wronged them: they can choose not to report the crime, or not to tell the police what they know; ${ }^{48}$ they can ask that the case be dropped, and the prosecutor might accede to that request. But they have no formal standing either to initiate or to drop prosecution, whereas in a tort case the claimant remains in control.

There are various ways in which we could reduce, if not eliminate, these differences - either by reconceptualising aspects of the criminal process, or by reforming it. As to vindication for the victim, one could suggest, first, that criminal trials should mark the logical and normative distinction between offences and defences more clearly in their procedure: the first stage of the trial would be concerned with whether the defendant committed the offence charged; if that was proved, the second stage would be concerned with whether he could offer a defence. Proof of the offence at the first stage, as a presumptive wrong for which the defendant must answer, would then provide vindication for victims who were non-culpably wronged. That would not quite deal with the problem of vindication, since some defences involve claiming that the 'victim' was partly or wholly responsible for the crime (self-defence being the most obvious example, and consent another): but we could also suggest, second, that courts should have to produce reasoned verdicts that explain the grounds on which the defendant is either convicted or acquitted, so making clear whether, in the court's judgment, the complainant was wronged. This suggestion, especially in the case of jury trials, has some challenging implications, but also has some independent plausibility, as a matter of due process. ${ }^{49}$

48 I leave aside the question of what duties victims might have to report the crimes they suffered, or to assist their prosecution: see S. E. Marshall, "It isn't just about you": victims of crime and their associated duties' in R. A. Duff et al. (eds.), Criminalization: The political morality of the criminal law (Oxford University Press, 2014).

49 See, e.g., Lord Justice Auld's Review of the Criminal Courts of England and Wales (London: HMSO, 2001), 168-73 and ch. 11 (though his recommendation that juries should be required to give reasons goes along with other recommendations about how their role and discretion should be constrained). 
As to punishment, some argue that we should transform the criminal process into something more like a civil process by abandoning punishment in favour of compensation or restitution, ${ }^{50}$ and criminal courts can make a compensation order against a convicted defendant instead of or in addition to dealing with him in any other way. ${ }^{51}$ We could also, and more plausibly, portray criminal punishment in ways that give talk of debt-paying more purchase. One who commits a criminal wrong thereby incurs a reparative debt: he owes reparation (apologetic reparation that addresses not just any harm caused, but the wrong done) to those he has wronged - not just to the direct victim, if there was one, but to the whole polity; criminal punishment is (or should be) the exaction of that debt. There are different ways of understanding that debt, and how punishment can pay it. We might talk, for instance, of the communication of an apologetic recognition of the wrong done, and of punishment as giving material force to that communication. ${ }^{52}$ Or we might argue that the offender can pay the debt by undergoing the punitive burden imposed by a penal system whose justifying aims are deterrent, ${ }^{53}$ incapacitative, or reformative. I am not here trying to defend such accounts of criminal punishment (or such proposals for its abolition): my point is only that if we understand tort damages as attempts not (just) to provide compensation for harm that was caused, but to make reparation for wrongs that were done, we can also see punishments imposed by criminal courts as closer in their meaning to the damages awarded by civil courts.

As to the victim's role in, or control over, the legal process, we could follow the example of some European systems, and give the victimcomplainant a larger, formal role in decisions about prosecution and also in the trial itself. We could, for instance, provide that prosecutions for some offences should proceed only at the request, or only with the

50 E.g. R. Barnett, 'Restitution: a new paradigm of criminal justice' (1977) 87 Ethics 279; D. Golash, The Case against Punishment: Retribution, crime prevention, and the law (New York University Press, 2005); D. Boonin, The Problem of Punishment (Cambridge University Press, 2008).

51 Powers of Criminal Courts (Sentencing) Act 2000, ss. 130-133. Indeed, if the court considers both a fine and a compensation order appropriate, but the offender has insufficient means to pay both, compensation should take priority: s. 130(12).

52 See R. A. Duff, Punishment, Communication and Community (Oxford University Press, 2001); C. J. Bennett, The Apology Ritual: A philosophical theory of punishment (Cambridge University Press, 2008).

${ }^{53}$ See V. Tadros, The Ends of Harm: The moral foundations of criminal law (Oxford University Press, 2011). 
consent, of the victim; ${ }^{54}$ or give the victim the right to seek a review of prosecutorial decisions not to proceed; ${ }^{55}$ or have some cases prosecuted by the victim; ${ }^{56}$ or allow the victim to join the case as a co-prosecutor; ${ }^{57}$ or allow the victim to attach her claim for compensation to the criminal case. ${ }^{58}$ All these possibilities go well beyond the limited provisions made in English and American criminal trials for Victim Impact Statements, Victim Personal Statements, or sentencing proposals by victims, ${ }^{59}$ and can be seen as giving more substance to the idea that the wrong being tried by a criminal court is not just our collective wrong, but the victim's wrong in particular.

I'm not here advocating any of these strategies either in our conceptualisation of the criminal process or in its actual operations; they are at best controversial, and at worst deeply problematic. My point is only that these are ways in which we could decrease the gap between our current tort and criminal processes, so that we see both as processes through which alleged wrongdoers are called to answer to those they allegedly wronged, and (if the wrongdoing is proved) required to make suitable reparation to them. Why should we do this? One reason is to work out whether the criminal process could do more to offer victims the kind of vindication that they must now seek through tort law; whether it could do more, when the wrongs with which it is dealing are directly victimising wrongs, to recognise the direct victim's distinctive standing. The third

54 Cf. the German category of Antragsdelikte (e.g. Strafgesetzbuch $\$ \$ 123,185-94,248 b$ ); Polish Criminal Code $\$ \$ 160.3,161,190$ (thanks to Krzysztof Szczucki for information about Polish law). Cf. also Stevens' suggestion, in this volume, Chapter 5.1.D that 'where crimes are only such because they constitute interpersonal wrongs, the victim should have control over whether a prosecution is brought'.

55 As is now provided in England: see Crown Prosecution Service, Victims' Right to Review Scheme (www.cps.gov.uk/victims_witnesses/victims_right_to_review/index.html), and $R$ (B) v. DPP [2009] 1 WLR 2072.

56 Cf. the German provisions for Privatklage (Strafprozessordnung $\$ \$ 374-94$ ); and Polish Criminal Code $₫ \$ 212,216-7$, ss. 157.2-3, 160.3, 190.1.

57 Cf. the German provisions for Nebenkläger (Strafprozessordnung $\$ \$ 395-402$ ), and the French provisions for instituting or joining in a criminal prosecution as a 'partie civile' (see further, Spencer's Chapter 11 in this volume, text preceding n. 17).

58 See e.g. Strafprozessordnung $\$ \$ 403-6$; and the Swedish provisions described in C. Lernestedt, 'Victim and society: sharing wrongs, but in which roles?' (2014) 8 Crim Law \& Phil 187.

59 See, e.g., Crown Prosecution Service, 'Victim personal statements' (http://www.cps.gov. uk/legal/v_to_z/victim_personal_statements/); A. J. Ashworth, 'Victim impact statements and sentencing' [1993] Crim LR 498; E. Erez, 'Victim participation in sentencing: and the debate goes on ...' (1994) 3 International Review of Victimology 17. 
issue noted above, about who has an active role in calling the alleged wrongdoer to account, is central here: the victim's role in our existing criminal process is often a purely passive one - at best, as the person to whom the wrong was done and to whom something is now owed; perhaps we should reconceptualise the legal role of victim in more active terms of what rights and powers victims should have. ${ }^{60}$ This raises a number of issues, which we cannot pursue further here, about just what the criminal process should offer victims or demand from them. It might be argued, against the suggestion that they should have a more active role, that we must preserve a clear separation, as the distinction between tort and criminal law preserves, between the victim's private interest in seeking some remedy for her wrong, and the public interest in the prosecution of crimes; but part of the point of suggesting that we should see crimes as shared wrongs was to suggest that the victim's wrong is taken up into the public realm, and itself becomes the public wrong with which the criminal law then deals. What is true, however, is that on this view the victim appears at the trial not simply as a private individual, but as one of the collective 'we' who share the wrong; the victim must speak not simply as an 'I', but in our voice.

The other reason for seeing whether and how we can reduce the differences between tort law and criminal law is simply to make clear the way in which, when tort law is understood and used as a matter of vindication for wrongs, the distinction between these two types of law becomes more porous, leaving us with a more nuanced set of choices about whether a legally cognisable wrong should be treated (only) as a tort or (only) as a crime - and about what either classification is to involve. Suppose that, whatever steps we take to bring tort and criminal processes closer to each other, we will see reason to maintain both kinds of process: a tort process through which individuals can, in their own voice and at their own discretion, seek vindication for wrongs they have suffered; and a criminal process through which we, as a polity, seek to call to account those who commit wrongs that we should make our own. When we then try to work out which kinds of wrong should belong to each process, we face two sets of decisions. The first concerns which wrongs should count as 'public', i.e. should be recognised by the law as wrongs for which a legal response or remedy should be

60 And what responsibilities or duties: see Marshall, “It isn't just about you”' (n. 48 above), and 'Victims of crime: their station and its duties' in M. Matravers (ed.), Managing Modernity: Politics and the culture of control (London: Routledge, 2005), 104. 
available, at all: ${ }^{61}$ more precisely, for which kinds of wrong should a legal response be available that makes their wrongfulness salient? The second set of decisions concerns which of those public wrongs should be defined as torts, which as crimes, and perhaps which as both. It seems plausible to say that every legally cognisable wrong with a direct victim is in principle eligible to be treated as a tort; and if a criminal process (even if reformed) cannot always provide victims with the kind of vindication that they might properly want, that such wrongs should count as torts even if they are also defined as crimes. But which types of wrong should be criminalisable?

\section{Criminalisable wrongs}

We might then identify three types of criminalisable wrong. First, there are the wrongs that lack an identifiable victim who could seek vindication (or, if the victim is dead or incapacitated, on whose behalf others could seek it) - wrongs whose only victim is the whole polity. ${ }^{62}$ We might say in such cases that the polity, rather than an individual victim, seeks vindication; the offender's punishment might then properly be seen as 'community payback'.

Second, we might identify a class of victimising wrongs that may be pursued as criminal, but only with the victim's consent, or only at the victim's request - and the difference between these two kinds of provision might be important. If what matters is the victim's request, we might say that these are wrongs which are sufficiently serious, or sufficiently inconsistent with the equal concern and respect that citizens owe each other, that we should not leave their victims with the burden (both moral and material) of having to seek vindication for themselves: we should, out of solidarity, be ready to pursue the wrongdoers collectively, to make the wrongs our wrongs - but only if the victims ask us to do so; if they would rather deal with the wrongs informally, outside the law, or pursue them as torts, or simply ignore them, we should not insist on taking them up. If what matters is the victim's consent, we might say that these are wrongs which we think ought to be pursued (indeed, that the victim ought to pursue them), for reasons to be noted below, but not so urgently

61 See text at nn. 37, 46 above.

62 A further question, which I cannot pursue here, will then be whether at least some such wrongs should be dealt with as 'civil' or administrative violations, rather than as properly criminal offences. 
that we should be willing to override the victim's wishes, or impose on the victim the burdens of the criminal process.

Third, we might identify another class of victimising wrongs (these might be the paradigm criminal wrongs) that we will be ready to insist on pursuing as criminal, even if the victim does not wish them to be pursued - wrongs that we will be ready to insist on sharing (or, as the victim might see it, taking over) as our wrongs, whether or not the victim wants to share them. This, as we saw earlier, is a hallmark of our existing criminal process, and is part of what motivates the charge of 'stealing conflicts'; the question then will be what, if anything, could justify this kind of insistence, in relation to which kinds of wrong. ${ }^{63}$

One kind of answer to this question takes us back to punishment as a distinguishing mark of criminal law: we have reason to insist on treating the wrong as criminal because we have a collective interest in punishing it; to which we might add that the victims of such wrongs then have a duty, owed to their fellow citizens, to assist in the prosecution of such wrongs. ${ }^{64}$ That interest might be preventive: we have a collective interest in reducing the incidence of such wrongs by deterrent, incapacitative, or reformative punishments. Or it might be retributive: if justice demands that such wrongs be punished, we have collective reason to see that they are punished. This makes punishment part of the rationale of criminalisation itself-we criminalise in order to be able to punish.

Another kind of answer is non-instrumental: we see these as wrongs that we must mark, whose perpetrators we must try to call to account, since not to do so would be to betray those values by which we profess to define ourselves as a polity - values that the wrong so flagrantly violates. For the law to remain silent about such wrongs, for it not to require that they be condemned and their perpetrators called to public, punitive account, would be to condone them; we have, and their victims thus also have, a duty to respond to them in a way that makes clear that they are not to be tolerated, or committed with impunity. Punishment might figure in this kind of answer, but not as the primary reason for criminalisation: we will see reason to punish such wrongs if and because that is an

63 This issue has become salient in the context of domestic violence: see M. M. Dempsey, Prosecuting Domestic Violence: A philosophical analysis (Oxford University Press, 2009). Even if the victim should not have a veto over the pursuit of such wrongs, our insistence on pursuing them must of course be sensitive to, and will sometimes be properly inhibited by, the harm that such pursuit might do, including especially harm to the victim.

${ }^{64}$ A claim often made in police procedural films, as police officers try to persuade the unwilling victim to make a formal complaint or to give evidence. 
essential dimension of holding their perpetrators properly to account. ${ }^{65}$ The Preamble to the International Criminal Court's founding statute is interesting here, when it seeks to identify (in admittedly rhetorical terms) the kinds of wrong that should fall within the ICC's jurisdiction: these are wrongs 'that deeply shock the conscience of humanity', that 'must not go unpunished'; the whole international community must 'put an end to impunity for [their] perpetrators ... and thus ... contribute to the prevention of such crimes'. ${ }^{66}$ The rhetoric is in part preventive, but also speaks to a sense that independently of such instrumental concerns, we must collectively respond to such wrongs (although we need to be very cautious both about the thought that we 'must' respond and about the form that a response should take).

\section{Concluding remarks}

I have not tried here to offer some set of determinate master principles or criteria by which we can decide which wrongs should be criminal, and which (only) tortious - I doubt that any such set of principles or criteria can be provided. My aim has been instead to show how, if tort law is (at least sometimes) concerned with the vindication of wrongs rather than with the allocation of costs, the distinction, and the proper division of normative labour, between tort law and criminal law become less clear cut. We might indeed, I have suggested, blur the distinction further, by revising our understanding of criminal law, and reforming the criminal process, in ways that make the vindication of victims' rights more central to criminal law, and give victims a more active role in the criminal process. In the end, however, we will still need to recognise a set of wrongs, many at least of which are victimising wrongs, which should be collectively pursued as wrongs even if the victim does not want this wrongs for which we recognise a collective duty to mark and condemn, and on whose perpetrators we recognise a collective duty to call to account. Such wrongs form the core of the criminal law as a distinctive kind of law: the question of which wrongs we should see as being of this kind is a crucial question not just for criminal law theorists discussing the issue of criminalisation, but for the process of public deliberation that ought to inform a democratic process of criminalisation.

65 See further Duff, Punishment, Communication and Community (n. 52 above).

66 Rome Statute of the International Criminal Court, Preamble. 